Biol. Stud. 2010: 4(1); 161-164 • DOI: https://doi.org/10.30970/sbi.0401.076

www.http://publications.Inu.edu.ua/journals/index.php/biology

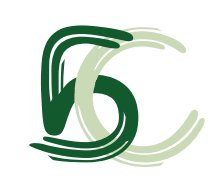

УДК [582.282+582.284]:581.557(477.83)

НОВІ ДЛЯ УКРАЇНСЬКОГО РОЗТОЧЧЯ ЛІХЕНОФІЛЬНІ ГРИБИ

M. В. Пiporos

Львівський національний університет імені Івана Франка вул. Грушевського, 4, Львів 79005, Україна e-mail: nikola.pirogov@gmail.com

Повідомлено про чотири нових для Українського Розточчя види ліхенофільних грибів: Athelia arachnoidea (Berk.) Jülich, Trichonectria hirta (A. Bloxam) Petch., Arthonia clemens (Tul.) Th. Fr. та Muellerella lichenicola (Sommerf.) D. Hawksw. Три із них вперше виявлені у фрізико-географічному регіоні Розточчя.

Ключові слова: ліхенофільні гриби, Розточчя.

Ліхенофільними (lichenicolous) називають неліхенізовані або ліхенізовані гриби, що розвиваються на чи у лишайниках як паразити, парасимбіонти або сапрофіти [11]. Ліхенофільні гриби належать до відділів Ascomycota та Basidiomycota, a також до групи анаморфних грибів.

Перші фрагментарні відомості про ліхенофільні ліхенізовані та неліхенізовані гриби України знаходимо у „Флорі лишайників України» [5-7], а також у „Визначнику грибів УРСР" [3, 4]. Спеціальне вивчення ліхенофільних грибів в Україні розпочате лише на початку 90-х років [10]. Протягом періоду від 1992 до 2009 років публікується низка статей, присвячених новим знахідкам ліхенофільних грибів на теренах України [1, 2, 8 та ін.]. На даний час найбільш повною роботою, присвяченою ліхенофільним неліхенізованим і ліхенізованим грибам України є стаття С.Я. Кондратюка, що вийшла у 1999 році [1]. Вона містить перелік відомих на той час видів, а також ключ для їх визначення.

Для Українського Розточчя за опублікованими даними [1-3] відомо три види ліхенофільних грибів: Pronectria robergei (Mont. \& Desmaz.) Lowen (Nectria lichenicola (Ces.) Sacc.), Nectriopsis lecanodes (Ces.) Diederich \& Schroers (Nectria lecanodes Ces.) та Opegrapha physciaria (Sommerf.) D. Hawksw., у той час як для Польського Розточчя [9] 7 видів: Athelia arachnoidea (Berk.) Jülich, Clypeococcum hypocenomycis D. Hawksw., Corticifraga fuckelii (Rehm) D. Hawksw. \& R. Sant., Lichenoconium erodens M.S. Christ. \& D. Hawksw. in D. Hawksw., Polycoccum peltigerae (Fuckel) Vězda, Scutula epiblastematica (Wallr.) Rehm ta Libertiella curvispora D. Hawksw. \& Miądlikowska.

Під час опрацювання гербарних колекцій лишайників Українського Розточчя нами виявлені деякі зразки лишайників уражені ліхенофільними грибами. Подаль- 
ше їх визначення за роботою С.Я. Кондратюка [1] та іншими роботами $[12,13]$ дозволило встановити їх видову приналежність. Ми визначили чотири види ліхенофрільних грибів: Athelia arachnoidea (Berk.) Jülich, Trichonectria hirta (A. Bloxam) Petch., Arthonia clemens (Tul.) Th. Fr. та Muellerella lichenicola (Sommerf.) D. Hawksw. Усі види грибів виявились новими для Українського Розточчя. Нижче подані місця збору гербарних зразків цих грибів. Усі зразки зібрано у Яворівському районі Львівської області автором і зберігаються на базі Гербарію кафедри ботаніки Львівського національного університету імені Івана Франка (LW). У круглих дужках подано дату збору зразка.

Athelia arachnoidea (Berk.) Jülich - дуже поширений на Українському Розточчі базидіальний гриб, розвивається на сланях Phaeophyscia orbicularis (Neck.) Moberg та Xanthoria parietina (L.) Th. Fr. Гриб має добре розвинутий павутинистий міцелій, що має вигляд білих або жовтуватих плям діаметром до 10-15 см, що розвивається на епіфрітних лишайниках та мохах, викликаючи їх відмирання. Плодові тіла кулясті до невизначеної форми, дрібні, кремового до темно-жовтого кольору, трапляються рідко. Гербарні зразки зібрано у м. Новояворівську, на корі стовбура тополі чорної (Populus nigra L.) на поверхні лишайників (24.06.06); на західних околицях смт Шкло, біля сірчаного кар'єру, Яворівського державного гірничо-хімічного підприємства „Сірка”, на корі стовбура тополі чорної, на мохах і лишайниках (15.10.05) та на околицях с. Лелехівка, на корі тополі біля дороги до села (17.04.08) (LW). Вид також широко поширений у Львові переважно на слані Phaeophyscia orbicularis на різних видах дерев.

Trichonectria hirta (A. Bloxam) Petch. - аскомікотовий ліхенофільний гриб, на Українському Розточчі трапляється рідко, виявлено на слані Trapeliopsis flexuоsa (Fr.) Coppins \& P. James. Гриб добре упізнається завдяки оранжевим блискучим перитеціям з жорсткими білими волосками, а також багатоклітинним червовидним спорам. Гербарний зразок зібрано в околицях м. Новояворівська, у сосновому лісі на корі сосни при основі стовбура на слані лишайника (18.10.08) (LW).

Arthonia clemens (Tul.) Th. Fr. - очевидно, досить поширений на Українському Розточчі аскомікотовий гриб. Розвивається на апотеціях Lecanora dispersa (Pers.) Sommerf. Ліхенофільний гриб добре помітний завдяки чорним плямовидним апотеціям, що розвиваються на поверхні плодових тіл L. dispersa викликаючи їх плямовидне або повне почорніння. На зрізах уражених апотеціїв $L$. dispersa добре помітними $€$ апотеції $A$. clemens із світло-коричневим до безбарвного гіменіальним шаром та темно-коричневим до чорного епітецієм. Сумки містять по 8 двоклітинних спор. Гербарні зразки зібрано у сірчаному кар'єрі в околицях с. Шкло, на каменях східного схилу, на апотеціях лишайника (01.04.03) (LW).

Muellerella lichenicola (Sommerf.) D. Hawksw. - очевидно, досить поширений на Українському Розточчі аскомікотовий гриб. Розвивається також на апотеціях Lecanora dispersa. Гербарний зразок зібрано там же, де і попередній вид. На зрізах уражених апотеціїв L. dispersa $€$ помітними коричневі гіфи, що біля поверхні плодового тіла фрормують темно-коричневі дрібні, повністю занурені кулясті та більші, майже повністю занурені видовжені перитеції з дрібним отвором на верхівці. Перитеції Muellerella lichenicola на апотеціях L. dispersa зовні помітні у вигляді дуже дрібних чорних крапок або взагалі не помітні, але добре помітні на зрізах завдяки коричневому забарвленню.

ISSN 1996-4536 • Біологічні Студії / Studia Biologica • 2010 • Том 4/№1 • С. 161-164 
Таким чином, на даний час за опублікованими даними та власними зборами вдалося встановити, що на Українському Розточчі трапляється 7 видів ліхенофрільних грибів. 3 них увперше для Українського Розточчя наведено 4 види, це Athelia arachnoidea (Berk.) Jülich, Arthonia clemens (Tul.) Th. Fr., Muellerella lichenicola (Sommerf.) D. Hawksw., та Trichonectria hirta (A. Bloxam) Petch. Три з них, Arthonia clemens, Muellerella lichenicola та Trichonectria hirta, наведено вперше для природного фрізико-географрічного регіону Розточчя.

1. Кондратюк С.Я. Ліхенофільні гриби України. У кн.: Вивчення різноманітності мікобіоти України (ліхенофільні, септорієві та пукцинієві гриби). Київ: Фітосоціоцентр, 1999: 8-43.

2. Кондратюк С.Я., Ходосовщев О.Є. Нові для мікобіоти України види ліхенофільних грибів. Укр. ботан. журн, 1997; 54(6): 588-590.

3. Морочковський С.Ф., Зерова М.Я., Лавітська З.Г., Сміцька М.Ф. Визначник грибів України. Т. 2. Аскоміцети. Київ: Наукова думка, 1969. 517 с.

4. Морочковський С.Ф., Радзієвський Г.Г., Зерова М.Я. та ін. Визначник грибів України. Т. 3. Незавершені гриби. Київ: Наукова думка, 1971. 696 с.

5. Окснер А.М. Флора лишайників України. В 2-х т. Т. 1. Київ: Вид-во АН УРСР, 1956. $495 \mathrm{c}$.

6. Окснер А.М. Флора лишайників України. В 2-х т. т. 2. Вип. 1. Київ: Наукова думка, 1968. $500 \mathrm{c}$.

7. Окснер А.М. Флора лишайників України. В 2-х т. т. 2. Вип. 2. Київ: Наукова думка, 1993. $541 \mathrm{c}$.

8. Федоренко Н.М., Надєїна О.В., Кондратюк С.Я. Нові та рідкісні види ліхенофільних грибів з України. Укр. ботан. журн, 2007; 64(1): 47-55.

9. Faltynowicz $W$. The lichens, lichenicolous and allied fungi of Poland - an annotated checklist. Kraków: W. Szafer Institute of Botany, 2003. 434 p.

10. Hawksworth D.L. Nine lichenicolous fungi from Transcarpathia new for the Ukraine. Ukr. Botan. Zhurn, 1992; 49(3): 99-100.

11. Kirk P.M., Cannon P.F., Minter D.W., Stalpers J.A. (Ed.). Ainsworth and Bisby's Dictionary of the Fungi. $10 \mathrm{Ed}$. Wallingford: CAB International, 2008. $771 \mathrm{p}$.

12. Parmasto E. Athelia arachnoidea, a lichenicolous basidiomycete in Estonia. Folia Cryptog. Estonica, 1998; 32: 63-66.

13. Purvis O.W., Coppins B.J., Hawksworth D.L. et al. (Ed.) The lichen flora of Great Britain and Ireland. London: Nat. Hist. Mus. Publ., 1992. 710 p.

\section{NEW LICHENICOLOUS FUNGI OF UKRAINIAN ROZTOCHYA}

\section{N. V. Pirogov}

Ivan Franko National University of Lviv, 4, Hrushevskyi St., Lviv 79005, Ukraine e-mail:nikola.pirogov@gmail.com

Four new species of lichenicolous fungi, Athelia arachnoidea (Berk.) Jülich, Trichonectria hirta (A. Bloxam) Petch., Arthonia clemens (Tul.) Th. Fr. and Muellerella lichenicola (Sommerf.) D. Hawksw., are cited for Ukrainian Roztochya. Three of these species are reported for the physical-geographical region Roztochya for the first time.

Key words: lichenicolous fungi, Roztochya. 


\section{НОВЫЕ ДЛЯ УКРАИНСКОГО РАСТОЧЬЯ ЛИХЕНОФИЛЬНЫЕ ГРИБЫ}

\section{Н. В. Пирогов}

Львовский национальный университет имени Ивана Франка ул. Грушевского, 4, Львов 79005, Украина e-mail: nikola.pirogov@gmail.com

Сообщается о четырех новых для Украинского Расточья видов лихенофильных грибов: Athelia arachnoidea (Berk.) Jülich, Trichonectria hirta (A. Bloxam) Petch., Arthonia clemens (Tul.) Th. Fr. и Muellerella lichenicola (Sommerf.) D. Hawksw. Три из них впервые обнаружены в фризико-географическом регионе Расточье.

Ключевые слова: лихенофильные грибы, Расточье.

Одержано: 16.03.2010 